\title{
Science journalism in Latin America: how the scientific information from a scientific source is accommodated when it is transformed into a journalistic story
}

\author{
Fernanda Veneu, Luis Henrique Amorim, Luisa Massarani
}

\begin{abstract}
Scientific information - from the moment it is produced by the scientific community until it reaches the nonexpert audience through the newspapers - is submitted to a complex process of adaptation. In this paper, we investigate the process of accommodating the scientific information provided by a primary scientific source (a peer-review journal) into journalistic discourse (a newspaper). As case studies we analyzed four scientific papers published by the peer-reviewed scientific journals Nature and Science, which were simultaneously used as primary scientific sources by Latin American newspapers. We observed that the process of accommodation into a new space, journalistic space, represents a significant shift in the content of the texts, including information that appears, disappears and is transformed in the process; transformations in the lexica, the style and the argumentation; a change in the hierarchy of the information; a shift in the information emphasized and in the social impact it might have.
\end{abstract}

\section{Introduction}

In the international context, various studies are identified on the coverage of matters of science and technology in daily newspapers (see, for example: [17],[5],[16], 4] in the United States, [7], [22] in Canada; [18] in Germany, [10], [2], [11] in the United Kingdom, [3] in Italy, [6] in India, only to cite a few).

In Latin America, there is a reduced number of studies in this direction (for example, [19] in Argentina and [21] in Colombia). Less frequent are the studies that seek to compare science journalism practiced in the specific countries of the region. In addition to this, a little-explored aspect in the analysis of science coverage in newspapers is the fact that the scientific information - from the moment that it is generated in the scientific community until it reaches the non-expert audience by way of newspapers - goes through a complex process of adaptation.

Following this line of thought, Fahnestock [8] seeks to show that this process of adaptation does not simply consist of a transformation of scientific jargon into non-technical equivalents. She affirms that it is, in reality, a change in discourse. In order to support her point of view, the author uses the Aristotelic model [1], which divides rhetoric into three genres of discourse: deliberative (which seeks to deliberate on questions of particular or general interest, with an eye on the future); demonstrative or epidictic (which is made up of discourses of praise or censorship, occurring, for example, in ceremonies or awards events; based in the present and generally concerned with solidifying the values of the audience); and judiciary or forensic (which refers to evaluations about nature and the cause of past events, in which diverse persuasion strategies are utilized).

For Fahnestock, the original scientific texts would be mainly "judiciary" texts, for they are essentially related to establishing the truth of the observations they record. One of the objectives sought out is the persuasion of the reader with regard to the correctness and the relevance of the new knowledge announced Science communication texts would be mainly "epidictic": their main objective would be to celebrate, rather than validate information.

${ }^{1}$ A Portuguese version of the article can be found in Massarani, Turney \& Moreira (2005). 
Based on the hypothesis that, in fact, there is a change of discourse when information is accommodated ${ }^{2}$ when it is taken from a scientific article and transformed into a journalistic report, Fahnestock compared original articles from Science with their scientific communication equivalents, published in Science82. Both of these are publications of the American Association for the Advance of Science aimed at different audiences.

Although having pointed out that the analysis of Fahnestock in some ways simplifies, given that it reduces the divulgating texts to their mere epidictic aspect, Massarani and Moreira [13] highlight the importance of studies that Fahnestock developed in order to understand what happens with scientific information in the process of accommodation in order to be directed to different audiences. Following Fahnestock's trail, the authors concentrated on two case studies of accommodation of primary scientific knowledge for divulgating texts. Said study raised interesting clues with regard to a qualitative analysis of scientific journalism and was the starting point of this study. Here we focus on four case studies, analyzing how scientific information from four scientific articles published in two of the most renowned international scientific journals, Nature and Science, was accommodated in the adaptation process carried out by newspapers in Latin America.

\section{Methodology}

This study is part of a broader research project entitled "Science journalism in Latin America", which analyzes the coverage of science in the region (see, for example, Massarani et al., 2005, Massarani and Buys, 2007). For this particular study, all the stories published in the science section in the month of April 2004 were analyzed in the following newspapers: La Nación, of Argentina; El Mercurio, of Chile; Reforma, of Mexico; El Comercio, of Ecuador; $O$ Globo, Folha de São Paulo and Jornal do Commercio/Pernambuco, from Brazil. One of the criteria for selection of the newspapers was to have a science editor and staff focused on the area. In addition to this, there are the most important newspapers of the country of origin. The Jornal do Commercio of Pernambuco was chosen because of the fact that it privileges regional research, outside of the Rio de Janeiro - São Paulo axis, where the largest part of Brazilian scientific activity takes place. Our choice by April was based on some factors. One of them is that we wanted to analyze a period of one month as an exploratory study, aiming to evaluate if a broader project on the Latin American coverage of science would make sense; in fact, we found interesting data, which leaded us later to consolidate a study involving nine countries in the region and an one-year analysis period ([12], 15]). The choice specifically for April was based on the fact that there are no festivities such as carnival or end of year festivities, which usually affect the science coverage that is, it could be in some way considered as a "typical" month; later we double checked if there was not any unusual scientific event that could provide an atypical feature (as observed, for example, when Dolly the sheep was cloned, during the space trip of a Brazilian astronaut, and the bird flu).

In total, 482 stories were collected through daily accessing of the newspapers' sites. Of stories analyzed, we detected 17 groups of articles published about coinciding topics which were generated from the same material provided by the scientific community: scientific articles and press-releases sent by scientific institutions. We sought out those topics which were published in four or more newspapers, reaching a subtotal of six groups. Of these six, we excluded two press releases, one from NASA and the other from a French research institution, and we focused on four groups of stories which originated with scientific articles published in the journals Science (two articles) and Nature (two articles). We considered that this would provide us with a more homogeneous object of study, given that the two journals have similar purposes. They also have similar mechanisms utilized for the dissemination of information among journalists, by sending to the editing desks beforehand information about the articles that will appear in upcoming editions.

In our study, we sought to analyze the transformations to which the original texts were submitted. The following items were considered: journalistic "pegs" used; the information which appeared, disappeared and was transformed in the process of accommodation; and errors, carelessness and incoherencies.

\footnotetext{
2 The authors of these studies follow the option of Massarani and Moreira (2002) of using the term "accommodating" used by Fahnestock (1993); other authors could prefer "adaptation", which is also used here interchangeably, or "transposition".

${ }^{3}$ We thank Luis Henrique Amorim and Bruno Buys, who also participated in the project "Science Journalism in Latin America".
} 
We compared the reports on the same topic among themselves and with the material received from the scientific magazines. In this process, we observed the information that was kept and that which disappeared, the stylistic and linguistic resources used, the titles, and the way of organizing the information. We also sought out similarities and differences in the journalistic practice of the countries and the means of communication involved.

The topics chosen were: announcement of the draft of the rat genome, primary source Nature, with stories in four newspapers; parthenogenesis in mice carried out by Japanese scientists, primary source Nature, with stories in six newspapers; cat fossil discovered in Cyprus with dating established at 9,500 years, primary source Science, with stories in four newspapers; 75-million-year-old necklace found in South Africa, primary source Science, with stories in four newspapers (see end for the list of scientific articles and reports, with their respective references).

\title{
3. Results
}

\subsection{The journalistic "pegs"}

In order to analyze the approach that journalists gave to the topics, we used, in addition to the content of the articles, the headlines and subheads, given that they summarize the ideas contained in the paragraphs that follow them and have as a function the capturing of the reader's attention and highlighting what the journalist or editor deems most important.

In the case of the sequencing of the rat genome, we could observe that all the newspapers gave direct and objective treatment of the scientific fact. An example of this are the titles: "Descifran el genome de la rata de albañal" (Rat genome deciphered) (La Nación), "La rata consigue su genoma" (Rat gets its genome) (El Mercurio), "Ratazana é o terceiro mamífero com genoma sequenciado" (Rat is the third mammal with sequenced genome) (Jornal do Commercio) and "Genoma dos ratos já tem rascunho" (Rat genome now has draft) (Folha de São Paulo). The title of the scientific article, "Genome sequence of the Brown Norway rat yields insights into mammalian evolution", contains information that was used very little in the process of accommodation of the reports. Three of the four newspapers refer to the scientific article in the lead. All the reports mention the applicability of the research. We did not observed a sensationalist treatment of the topic by part of the newspapers, as also occurred in some of the cases that follow.

Of the four newspapers that published articles about the cat fossil discovered in Cyprus, three titles indicated a differential treatment of the topic: "9.500 años de gatos en casa" $(9,500$ years of cats in the home) (El Mercurio), "Hace 9500 años el gato ya era amigo del hombre" (For 9,500 years, the cat has been man's friend) (La Nación), "Gato e homem já convivem há 9500 anos" (Cat and man have lived together for 9,500 years) (Folha de São Paulo). These are in opposition to the more conventional "Hallan antiguo fósil de gato domesticado" (Old Fossil of domesticated cat found) (Reforma), which focused more on the archeological discovery itself.

In Folha de São Paulo, the journalist play with the figure of the cat and contrast is shown in relation to the time of human existence with dogs:

\begin{abstract}
Garfield, Sylvester, Felix the Cat and Tom would not pay much attention to this news. With the same degree of independence and arrogance as their less famous peers, domestic cats, they would only remember the "obvious": the importance of the company of felines for that awkward animal that, without any modesty, baptized himself as Homo sapiens, "sage", yet incapable of hunting mice efficiently, even with a hammer in his hand. The oldest proof of cohabitation of cats and humans has now been discovered, on the Mediterranean island of Cyprus, dating to no less than 9500 years ago. (...) (Folha de São Paulo, 04/09/2004).
\end{abstract}

In three of the newspapers that covered the discovery of the 75-million-year-old necklace in South Africa, vanity is exhibited as a characteristic that has accompanied humanity since its primordial times, as well as the inestimable value of the "jewel". The Folha de São Paulo adopted the conventional headline "African grotto holds 75-million-year-old necklace", but it follows a different line of thought throughout the text: 
(...) The world's oldest jewels were discovered by archeologists in South Africa. They did not contain gold, silver or diamonds, but they are a treasure which is more important than these vile metals and precious stones usually are. (...) About 75 million years ago there was a human being who took the trouble to pierce dozens of small shells and join them together into a necklace to use as an ornament. It is the oldest-known case of this aesthetic desire, 30 million years before the first known record. (Folha de São Paulo, 04/16/2004).

The report from La Nación has a suggestive title: "Coquetería prehistórica" (Pre-historic vanity). The highlight of the spectacular character discovered is shown in the first paragraph:

A group of European and African archeologists have just confirmed that vanity is a definitive and inescapable human impulse: they found 41 small shells used as a decoration no more, no less than 75 million years ago! (La Nación, 04/16/2004).

The articles published in $O$ Globo and Reforma are straightforward. In the story from $O$ Globo, entitled "75-million-year-old Human ornaments discovered in South Africa", the fact that alterations in behavior and appearance that characterize modern man have occurred simultaneously is used as "hook". In Reforma, the article "Old art discovered" gives a more refined character to the discovery by associating the necklace with art.

The birth of the female mouse Kaguya without fecundation (parthenogenesis) had particularities in the way the topic was dealt with on the part of the newspapers analyzed. As the technique was applied to mammals, it gave margin to speculate that it could also be used in human beings - a recurring aspect in the approach of all of the newspapers, but not mentioned in the scientific article. The ethical implications (not mentioned by Science) and the innovative character of the technique were cited by all of the newspapers. It is worth noting that the five-page scientific article gave little emphasis to the mouse itself and more emphasis to the technique. However, the animal became the center of attention in the media. The limited attention given to the animal by the authors of the scientific article could have been a strategy - yet perhaps not necessarily conscious - in order to not bring into focus eventual controversy and ethical questions around the experiment.

The headlines are expressive: "Revolución genética: japoneses generaron ratón sin padre" (Genetic revolution: Japanese create rat without father) (El Mercurio), “Serán prescindibles los hombres?” (Are men necessary?) (La Nación), "Obtienen ratón sin padre" (Rat obtained without father) (Reforma), "Rato criado a partir de dois óvulos e sem clonagem" (Rat created from two eggs and without cloning) (Jornal do Commercio), "Japão cria fêmea sem pai com duas mães" (Japan creates female without father with two mothers) (Folha de São Paulo), "Nasce mamífero sem pai e com duas mães" (Mammal born without father and with two mothers) (O Globo).

The spectacular character of the discovery highlighted in some newspapers (emphasis added):

A dogma of science was broken yesterday with the announcing of the birth of the first mammal that has two mothers and no father. (...) The birth of a live mammal by parthenogenesis was considered the most revolutionary fact in reproductive biology since the cloning of the sheep Dolly (...). (O Globo, 04/22/2004).

Scientists (...) have just crossed a frontier of biology that, until today, was believed to be uncrossable: they created a rat "without a father", in other words, from an embryo that was produced from two ova, without fertilization, without spermatozoons and without male genetic material. (Nora Bär, La Nación, 04/22/2004)

Since the appearance of mammals and of the ancestors of humans, millions of years ago, their reproduction required, except in very recent exceptional cases with clones, the intervention of a spermatozoon and an ovum. But this could be changed, according to results published today in the magazine Nature by a group of scientists (...) that obtained rats from an ovum without the need to fertilize it with spermatozoons. (Reforma, 04/22/2004)

In the body of the text, we can observe a tone of concern (emphasis added): 
Nature in danger yet again. If this work were to apply to human reproduction, it would have an ethical transcendence without precedent. Homosexuals, of both genders, could have children. (...) A child could also born without a mother. (El Mercurio, 04/23/2004)

Among the subheadings, the following stood out: "Nascimento por imaculada concepção" (Birth by immaculate conception) (O Globo), "Alerta roja" (Red Alert) (El Mercurio), "Es increíble" (It's incredible) (La Nación).

The Folha de São Paulo, with an all-male staff, decided to make a provocation:

A toast to radical feminism: scientists announced the birth of the first mammal that is the child only of the mother. Actually, of two mothers. (Folha de São Paulo, 04/22/2004).

The Jornal do Commercio kept more to the research and the technical explanation, without much mention of the ethical implications, in contrast to the other newspapers.

\subsection{Information that appears, disappears or is transformed}

Upon comparing the material analyzed with the original scientific article, we note the absence of some types of information present in the source articles. In the stories related to archeological discoveries, the techniques used by scientists to date the finds were suppressed - of great importance for the academic world, but generally considered by journalists and editors as being of lesser value for the lay public. The technique and the methodology also did not get space in the reports about the sequencing of the rat. The exception was the reports on the parthenogenesis of mice, in which the technique used was part of the news.

In the article on the sequencing of the rat genome, the fact that the original text has 28 pages is noteworthy. The emphasis given to the topic by the scientific publication did not have such a significant reflection in the general press (in general, around 1,500 characters). The scientific text on the mouse Kaguya, five pages in length, received more space in the newspapers (around 8000 characters in $L a$ Nación and around 4000 characters in the other newspapers).

In addition to this, some crucial information was neglected in the analyzed cases. This occurred with the sequencing of the rat genome, in which none of the newspapers analyzed mentioned that only the genes of the X chromosome were mapped. The fact that Rattus norvegicus is a species which is used more to research illnesses or test new medication was also absent from the reports (with the exception of El Mercurio). The information is found in the first sentence of the article published in Nature: "The laboratory rat (Rattus norvegicus) is an indispensable tool in experimental medicine and in the development of medicine, having made inestimable contributions to health".

In the case of the mouse Kaguya, only two of the four newspapers (El Mercurio and Folha de São Paulo) notified that the mouse had already had offspring through the natural method, one of the key points of the scientific article. The title itself of the scientific article, "Birth of parthenogenetic mice that can develop to adulthood", highlights the importance of the animal being able to reach adulthood.

Inserting information is also an important part of the process of accommodation. Data and additional explanations, historical information and paraphrasing were resources used in the articles analyzed. We highlight below an example taken from the article on the parthenogenesis of mice which appeared in the newspaper $O$ Globo, entitled "Mammal born with no father and two mothers":

What is parthenogenesis? It is a form of reproduction in which the ovum generates a new individual without fertilization. Natural parthenogenesis has already been observed in numerous animal species, particularly insects. Unfertilized ova of bees and ants generate males and the fertilized ova, workers and queens. (...) (O Globo, 04/22/2004)

Another way of inserting information and broadening the topic being dealt with in the report is by interviewing researchers who are not linked to the study in question. In many cases, they are from the country of the newspaper, exemplified in the four case studies analyzed here. 


\subsection{Errors, carelessness and incoherencies}

Throughout our study, we identified errors, carelessness and/or incoherencies in the published reports. A large part of them referred to numerical data or translations which were done in a hurried manner. This was the case with the discovery of the cat fossil, buried beside a human being. The original text says: "The cat skeleton was located in the same stratigraphic unit and just $40 \mathrm{~cm}$ from a human burial". See now an extract from one of the reports (emphasis added):

The skeleton of a cat of $40 \mathrm{~cm}$ was found by Jean-Denis Vigne and his colleagues of France's National Museum of Natural History. (Reforma)

In relation to the case of the mouse Kaguya, Sylvia Maestrelli, of the Federal University of Santa Catarina, points out that there was great distortion between what was written in the scientific article and what was published by daily newspapers:

The nine researchers did the impossible and got around all biological laws in order to achieve the parthenogenetic mammal (imprinting is a mechanism described only relatively recently in genetics and is very important, today scientists believe that we still know very little about it). It was a highly specialized experiment (they had to know which genes were "imprinted" and important in the development of the mouse, and find an adequate mutant for the experiment). They constructed 598 oocites, which began to die along the way, before two of them were born and Kaguya survived. The moral of the story: the last sentence of the summary is, as expected, the conclusion of the work, which says clearly that the paternal contribution is obligatory for lineage. And what did the articles of scientific communication do? They dressed themselves up with catchy headlines and said exactly the opposite of what the scientists said.

We observed that the error pointed out by the researcher was recurring in all five newspaper articles that resulted from the scientific article. Having this in mind, we reread the original text, which is quite technical and not very palatable for journalists. We did not find clues that showed what led to such an error. Thus, we sought out the press release sent to the journalists. Entitled "Are men unnecessary?", here is the first paragraph:

Men beware. Researchers obtained live mice through parthenogenesis. This means without spermatozoon, without male chromosomes, and without the need for men. The study is described in this week's Nature.

As we could see, in this case, the error was induced by Nature itself. Semir and Revuelta ([23] page 114) comment on this type of error, highlighting that such errors are more common than we imagine:

The search for rigor, transparency and objectivity that characterize the peer-review system which are the base of credibility of scientific magazines - many times are lost along the way in the moment that press releases which are sent to journalists are produced. This can have disastrous consequences, given the impact that press releases have over the means of communication and these, in turn, have on society, including the scientific community, which naturally gets information through these same sources.

\section{Final considerations}

In this article, we aimed to analyze the process of accommodation of scientific information from its original source - in this case, a scientific article - until the point in which it is transformed into a journalistic article. A first aspect that caught our attention at the beginning of this study was the fact that, in a period of 30 days, we identified 17 coinciding topics, with reports generated from one article provided by the scientific community.

\footnotetext{
${ }^{4}$ We thank Sylvia Maestrelli for having evaluated the scientific content of the stories, in comparison with the original article in
} Nature (comments made by email on June 18, 2006). 
We observed an important presence of journalistic articles resulted from initiatives such as those of Nature and Science, which send to journalists press releases on the scientific articles of their upcoming edition to journalists of different countries beforehand. Our data suggest that such initiative by these journals of sending the press release to the newspapers have been well accepted by the journalists, having impact in the science coverage. These initiatives guarantee that information previously submitted to a process of peerreview is available for Latin American journalists. However, as a side effect of this, we observed - similar to what happens in various other countries - a great homogenization of topics in science coverage. Many times this takes place by following the interests of other countries, in detriment to regional questions.

In spite of this homogenization of topics and of reports having been generated from the same primary source, we observed that the final products, in many cases, are quite different. Many times, the articles reproduce the information that arrives at the copy desks, without a critical approach. Other times, an important attempt to give meaningful local "color" is noted, bringing the novelty to the regional reality.

In accordance with our initial presupposition, we could observe that the process of accommodation represents a significant change in the content of the texts, which includes the existence of information which disappears, appears or is deliberately altered; the lexical and stylistic transformations as well as transformation of arguments; a change in the hierarchy of information; a change in the emphasis in information and in the social impact that it can have. Such alterations can be chalked up to the "incompetence" of some journalists, as is defended rather frequently in forums that seek to discuss the relationship between scientists and journalists. Errors and distortions exist, this is certain. However, in various cases, this is a simplistic explanation. More than a mere distortion of the scientific fact, the process of accommodation of scientific information can follow the ideology of the authors and the redefinition itself of information in a new space - the journalistic space.

Translated by Robert Gartner

\section{References}

[1] Aristóteles, Arte Retórica e Arte Poética. Rio de Janeiro, Ediouro, 1984.

[2] M. Bauer, A. Ragnarsdóttir, A. Rúdólfsdóttir, Science and Technology in the British Press, 19461990 - A systematics content analysis of the press, work report, 1993.

[3] M. Bucchi, R. Mazzolini, Big science, little news: science coverage in the Italian daily press, 1946-1997, Public Understanding of Science, 12: 7-24, 2003.

[4] F. Clark, D. Illman, A Longitudinal Study of the New York Times Science Times Section, Science Communication, 27(4): 496 - 513, 2006.

[5] C. Condit, Science reporting to the public: does the message get twisted?, CMAJ, 170 (9), 2004. Available: http://www.cmaj.ca/cgi/content/full/170/9/1415 (accessed on 28 January 2008)

[6] B. Dutt, K.C. Garg, An overview of science and technology coverage in Indian English-language dailies, Public Understanding of Science, 9: 123-140, 2000.

[7] E. Einsiedel, Framing science and technology in the Canadian press, Public Understanding of Science 1: 89-103, 1992.

[8] J. Fahnestock, Accommodating science: the rhetorical life of scientific facts, in MCRAE, M.W. (Ed.) The Literature of Science - perspectives on popular scientific writing, Georgia, The University of Georgia Press, 1993.

[9] Ferreira, Novo Aurélio Século XXI: o dicionário da língua portuguesa, Rio de Janeiro, Nova Fronteira, 1999.

[10] Hansen, R. Dickinson, Science coverage in the British mass media: Media output and source input, Communications 17 (3): 365-77, 1992.

[11] Hargreaves, J. Lewis, T. Speers, Towards a better map: science, the public and the media, Swindon, Economic and Social Research Council, 2002.

[12] L. Massarani, B. Buys, L. Amorim, F. Veneu, Jornalismo científico na América Latina: um estudo de caso de sete jornais da região, Journal of Science Commnunication, 4 (3), September, 2005. Available at: http://jcom.sissa.it/archive/04/03/A040302/, Accessed on October 15, 2007.

[13] L. Massarani, I. Moreira, A retórica e a ciência: dos artigos originais à divulgação científica, Ciência \& Ambiente, 23 - Jul. Dec. 2001. 
[14] L. Massarani, J. Turney, I. Moreira, (Org.) Terra incógnita - a interface entre ciência e público. Rio de Janeiro, Vieira \& Lent, 2005.

[15] L. Massarani, B. Buys, Science in the press: A study case on science coverage in Latin American nine countries, Brazilian Journalism Research, 3: 77-96. 2007.

[16] M.C. Nisbet, B. Lewenstein, Biotechnology and the American Media: The Policy Process and the Elite Press, 1970 to 1999, Science Communication, 23(4): 359-391, 2002.

[17] M.G. Pellechia, Trends in science coverage: A content analysis of three US newspapers, Public Understanding of Science 6: 49-68, 1997.

[18] H. Peters, The interaction of journalists and scientific experts: Co-operation and conflict between two professional cultures, Media, Culture and Society 17:31-48, 1995.

[19] C. Polino, D. Chiappe, M.E. Fazio, Análisis de la oferta informativa sobre ciencia y tecnología en los principales diarios argentinos, Final information, 2006.

[20] C. Polino, D. Chiappe, M.E. Fazio, Los hallazgos científicos en salud en los diarios de América Latina: ¿Qué se ofrece al público lector?, I Congreso Iberoamericano de Ciencia, Tecnología, Sociedad e Innovación, Ciudad de México, 2006.

[21] C. Rozo, Cultura científica y tecnológica en la prensa nacional, I Congreso Iberoamericano De Ciencia, Tecnología, Sociedad e Innovación, Ciudad de México, 2006.

[22] M.A. Saari, C. Gibson, A Osler, Endangered species: science writers in the Canadian daily press, Public Understanding of Science, 7: 61-81, 1998.

[23] V. Semir, G. Revuelta, El Dr. Hwang y el clon que nunca existió, Quark, 37-38: 105-123, 2006.

\section{Reports analyzed}

- Barba, "Obtienen ratón sin padre", Reforma, April 22, 2004.

- Barba, "Descubren arte antiguo", Reforma, April 15, 2004.

- Barba, "Hallan antiguo fósil de gato domesticado", Reforma, April 8, 2004.

- "COQUETERIA Prehistórica. Descubren adornos de hace 75.000 anos, La Nación, April 16, 2004.

- "Descifran el genoma de la rata de albañal, La Nación, April 1, 2004.

- L. Duery, "Revolución genética - japoneses generan ratón sin padre", El Mercurio, April 23, 2004.

- M. Fox, "Genoma dos ratos já tem rascunho", Folha de S. Paulo, April 1, 2004.

- "La rata consigue su genoma", El Mercurio, April 1, 2004.

- "Nasce mamífero sem pai e com duas mães", O Globo, April 21, 2004.

- R. Bonalume, "Gruta africana guarda colar de 75 mil anos", Folha de S. Paulo, April 16, 2004.

- R. Bonalume, "Gato e homem já convivem há 9.500 anos", Folha de S. Paulo, April 9, 2004.

- "Ornamentos humanos de 75 mil anos descobertos na Africa do Sul”, O Globo, April 15, 2004.

- "Ratazana é o $3^{\circ}$ mamífero com genoma seqüenciado", Jornal do Commercio, April 1, 2004.

- "Rato criado a partir de 2 óvulos e sem clonagem", Jornal do Commercio, April 23, 2004.

- Smith, "9.500 anos de gatos en casa", El Mercurio, April 9, 2004.

\section{Scientific articles analyzed}

- C. Henshilwood, F. d'Errico, M. Vanhaeren et al. "Middle stone age shell beads from South Africa", Science, v.304: 404, April 16, 2004.

- T. Kono, Y. Obata, Q. Wu et. al. "Birth of parthenogenetic mice that can develop to adulthood", Nature, v.428, April 22, 2004. p. 860-864.

- R. Gibbs, G. M. Weinstock, M. L. Metzker et al. "Genome sequence of the Brown Norway rat yields insights into mammalian evolution", Nature, v.428, April 1, 2004. p. 493-521.

- J.-D. Vigne, J. Guilaine, K. Debue et al., "Early taming of the cat in Cyprus", Science, v.304, April 9, 2004. p. 259. 


\section{Authors}

Fernanda Veneu is a $\mathrm{PhD}$ student at the Oswaldo Cruz Institute, Oswaldo Cruz Foundation (Fiocruz) (Brazil) in the Bioscience and Health Education Program. E-mail: Eveneu@gmail.com.

Luis Henrique Amorim is Brazilian science journalist. His master degree was obtained at the Bioscience and Health Education Program/Oswaldo Cruz Institute/Fiocruz. He is editor of the Jornal da Ciência, a newsletter on science policy published by the Brazilian Association for the Advancement of Science.

E-mail: luis@jornaldaciencia.org.br.

Luisa Massarani is a Brazilian science journalist. Her doctoral degree was obtained at the Federal University of Rio de Janeiro. She works in both practical and academic activities. She coordinates the Nucleus of Studies on Science Communication of the Museum of Life/Oswaldo Cruz House/Fiocruz Brazil) and the website SciDev.Net/Latin America and the Caribbean (www.scidev.net).

E-mail: luisa.massarani@pq.cnpq.br. 